\title{
Growth anomalies in Protothaca thaca (Mollusca, Veneridae) shells as markers of ENSO conditions
}

\author{
Claire E. Lazareth*, Grégory Lasne, Luc Ortlieb \\ PALEOTROPIQUE, Centre IRD (Institute de Recherche pour le Développement) d'Ile de France, 32 avenue Henri Varagnat, \\ 93143 Bondy Cedex, France
}

\begin{abstract}
Environmental variations can be recorded in bivalve shells, and this proxy information can be crucial for paleoceanographic studies in regions where other proxies (e.g. corals) are absent. We present the first sclerochronological study of Protothaca thaca (Mollusca, Veneridae), a common upper subtidal bivalve, characterized by a high temperature tolerance, from the SE Pacific Ocean (12 to $\left.45^{\circ} \mathrm{S}\right) . P$. thaca is present in archaeological deposits and Holocene marine terraces, making it a potentially useful paleo-environmental recorder, particularly in respect to El Niño Southern Oscillation (ENSO) reconstructions. The sclerochronological analysis of recent $P$. thaca shells from Peru and Chile was done by microscopy of thin sections and acetate peel replicates; it shows that a clear 'summer check' (SC) is formed in the shell when sea surface temperature (SST) exceeds $18^{\circ} \mathrm{C}$ for several weeks. Under La Niña conditions in summer, SCs can be absent due to lower SST and enhanced productivity. During the strong 1997-1998 El Niño, long-lasting high summer SST produced an SC $>520 \mu \mathrm{m}$ wide. The relative width of SC on fossil shells may thus be an indicator of paleo-ENSO events. Our sclerochronological analysis has established a temporal framework in $P$. thaca shells, providing precise time-series analytical profiles, which is a prerequisite for future calibration of geochemical proxies.
\end{abstract}

KEY WORDS: Bivalve · Protothaca thaca · Peru · Chile · Sclerochronology · El Niño Southern Oscillation

\section{INTRODUCTION}

Bivalve shell growth is a step by step process. Growth layers are successively added at the edge and inner surface of the growing shell. The thickness of the increments and the frequency at which they are added are governed not only by animal physiology (e.g. reproduction, ontogeny), but also by environmental variations (e.g. tidal cycle, water temperature, storm events, food availability). The study of shell microstructure periodicities, sclerochronology, can thus give information on both life history and environmental variations that occurred throughout the lifetime of the animal (reviews by Lutz \& Rhoads 1980, Richardson 2001). Yearly to daily periodicities can be observed in the succession of shell increments. Growth rings (also named 'checks' or 'breaks') are formed in the shell when growth is redu- ced or stopped during temperature extremes, e.g. in summer and/or winter (e.g. Jones \& Quitmyer 1996). The growth rings can be counted to deduce the lifespan of fossil and living specimens (Jones 1983 and references therein). Many bivalve species deposit microgrowth increments, usually named 'daily growth increments'; their width and number per year generally decreases with ontogeny (Hall et al. 1974, Jones 1981, Tanabe 1988). Formation of daily increments and some of their variability in width are related to tidal rhythms (e.g. Richardson 2001, Schöne et al. 2002a, 2003) and temperature (Kennish \& Olsson 1975, Jones 1981, Goodwin et al. 2001, Schöne et al. 2005). Schöne et al. (2002b) used age-detrending methods and Fourier filters to remove the ontogenic trend and tidal cycles from daily growth data in Chione cortezi and extract a sea surface temperature (SST) signal. 
The SE Pacific region is of particular importance for understanding the El Niño phenomenon. El Niño events along the Peruvian and north Chilean coasts re-

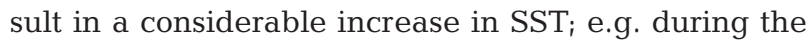
very strong $1982-1983 \mathrm{El}$ Niño, SST rose by $10^{\circ} \mathrm{C}$ during several weeks (Arntz 1986). At present, marine sediment records off Peru and Chile do not provide sufficient resolution to document such short term climatic events. Corals could provide high-resolution proxy records of El Niño occurrences, but in the cool waters of the Humboldt Current there are no coral species that can be used for paleo-environmental reconstructions.

Mollusc shells could supply a proxy record of El Niño events. The presence of easily readable shell growth anomalies may provide evidence of ENSO related events for specific Holocene periods. Bivalve shells (Chione subrugosa and Trachycardium procerum) from Peru have recorded the 1982-1983 El Niño both in the shell microstructure (growth anomaly) and in the shell isotopic signature (Rollins et al. 1987, Perrier et al. 1994). Similar features have been observed in fossil $T$. procerum shells and this is interpreted as reflecting El Niño occurrences during the Mid-Holocene period (Perrier et al. 1994). Carré et al. (2005) determined $\delta^{18} \mathrm{O}$ in archaeological Mesodesma donacium shells to study early Holocene El Niño events. However, the use of $M$. donacium shells as archive of El Niño event occurrences is problematic, since this species is particularly sensitive to temperature increases. $M$. donacium populations suffered high mortality during the 1982-1983 and 1997-1998 El Niño events (Arntz \& Tarazona 1990, Barriga \& Quiroy 2002).

Protothaca thaca may be a more appropriate environmental and paleo-environmental recorder, because its high temperature tolerance (Urban 1994) makes it one of the most resistant species to the effects of El Niño events in the SE Pacific region. A study of $P$. thaca shell geochemistry (El Jouhari et al. 2001) indicates that the 1997-1998 El Niño was registered in the stable oxygen isotope composition of the carbonate. Moreover, $P$. thaca is found in Holocene archaeological deposits of Peru (Reitz 1988, Moore 1991, Perrier et al. 1994) and in Pleistocene marine terrace units in southern Peru and Chile (Ortlieb et al. 1992, 1996). P. thaca may thus potentially provide useful palaeoceanographic and paleoclimatic data along the coast of the East Pacific Ocean, south of central Peru. However, unlike other Veneridae species, e.g. Mercenaria mercenaria (Jones \& Quitmyer 1996), Artica islandica (Witbaard 1997, Buick \& Ivany 2004), Chione sp. (Schöne et al. 2002a), and Protothaca staminea (Takesue \& van Geen 2004), P. thaca shells do not have conspicuous growth patterns. Therefore, a study of $P$. thaca was undertaken to determine if temporal and environmental information can be extracted from growth patterns in its shell. This study aimed to provide the sclerochronological framework for future geochemical analysis oriented towards a validation of $P$. thaca for paleo-El Niño reconstructions.

This is the first sclerochronological analysis of the Peruvian-Chilean Protothaca thaca shell. It is based on (1) microscopic observations on thin sections and acetate peel replicates and (2) correlation between growth increment widths and water temperature recorded during growth. Our study shows that a 'summer check' (SC) is formed in the shell when SST is $>18^{\circ} \mathrm{C}$ for $>3 \mathrm{wk}$. Under La Niña summer conditions, SCs can be absent. Finally, the widest SCs are related to the strong 1997-1998 El Niño, emphasising the potential of $P$. thaca shell as recorder of past ENSO events.

\section{MATERIALS AND METHODS}

\subsection{Samples}

Protothaca thaca is a subtidal marine bivalve (Veneridae) that lives up to an age of $7 \mathrm{yr}$ in shallow water depth (maximum $20 \mathrm{~m}$ ), just below the surface of sandy substrates (Urban 1994, Urban \& Campos 1994). It has a wide distribution range $\left(12\right.$ to $\left.45^{\circ} \mathrm{S}\right)$ and lives in water temperatures between 5 and $26^{\circ} \mathrm{C}$ (Urban 1994). Urban (1994) showed that $P$. thaca survives El Niño events, thanks to its high lethal temperature threshold $\left(\mathrm{LT} 50=27.9^{\circ} \mathrm{C}\right)$ and high tolerance to rapid temperature increases $(<50 \%$ mortality in the case of an abrupt increase by $\left.14^{\circ} \mathrm{C}\right)$. $P$. thaca specimens were studied at 2 sites: Pocoma, Peru $\left(17^{\circ} 25^{\prime} \mathrm{S}, 71^{\circ} 22^{\prime} \mathrm{W}\right)$ and $\mathrm{El}$

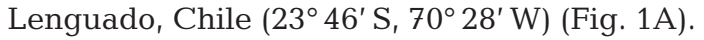

The 4 Pocoma shells studied belong to a population for which the growth of individuals was followed from at least May 2003 to September 2003; 85 individuals were put in net-bags fixed to the bottom in situ. Once per month, the Protothaca thaca specimens were removed and immersed for $3 \mathrm{~h}$ in a bucket with seawater and $100 \mathrm{ppm}$ of calcein; 2 specimens were taken after each marking, while the others were replaced in situ until the next marking. Then 4 specimens, 2 specimens with an initial marking from May 15, 2003 (PC77, PC134) and 2 with an initial marking from July 16, 2003 (PC50, PC127) were used for growth increment measurements. These specimens were sacrificed on 16 July 2003 (PC77), 14 August 2003 (PC50) and 21 September 2003 (PC127), (PC134). Daily SST data were obtained from the Ilo Station of the Instituto del Mar del Perú (IMARPE), which is near the Pocoma site (Fig. 1A).

Shells of dead Protothaca thaca were collected on the beach at El Lenguado in December 2000. Only specimens with articulated valves, i.e. from individuals 
that had died only a few days earlier, were used. From this sample, 6 specimens were randomly selected for the study of shell growth anomalies.

\subsection{Sclerochronological methodology}

The Protothaca thaca shell consists of 2 aragonitic layers, an inner homogeneous layer and an outer prismatic layer, where the growth increments are largest and can be more easily observed (Fig. 1B). Growth marks were identified by macroscopic observation of the shell surface, light microscopy and scanning electron microscopy (SEM). Shells were cut along their maximum growth axis using a high precision diamond saw (Isomet 5000 Buehler). The 4 Pocoma shell sections were polished and acetate peel replicates were made after etching with $10 \%$ acetic acid for $30 \mathrm{~s}$. Microstructural growth units and growth anomalies were identified by combining diffused and transmitted light microscopic observations of thin sections and acetate peels, and SEM imaging (Philips 505). The width of each thinnest growth increment was measured on the acetate peel replicates of the 4 Pocoma samples under an optical microscope with a precision of $5 \mu \mathrm{m}$. One valve of each of the $6 \mathrm{El}$ Lenguado specimens was cut as stated above and the thickness of the major growth anomalies was measured on thick polished sections with a precision of $5 \mu \mathrm{m}$ under an optical microscope with diffused light.

\section{RESULTS}

\subsection{Microgrowth increments}

The thinnest clearly bounded growth increments have a width of 10 to $120 \mu \mathrm{m}$ and are limited by a 3 to $5 \mu \mathrm{m}$ thick line of organic matter (black in transmitted light, etch-resistant) (Fig. 1C). These microgrowth increments are thinner in the last stages of life of the individual, reflecting the growth rate decrease related to ontogeny (see Fig. 3). Increment width variations at the margin of sample PC127 showed cycles varying from 6 to 14 increments. The beginning/end of each cycle are characterized by a small groove on the surface of the shell, as reported in other bivalves (e.g. Chione cortezi: Schöne et al. 2002a); this cyclic pattern is thought to coincide with tidal cycles. As tital mode here is semidiurnal with a diurnal inequality (see Dirección de Hidrografía y Navegacíon; http://www.dhn.mil.pe), the microgrowth increments defined above can thus be interpreted as 'daily' growth increments.
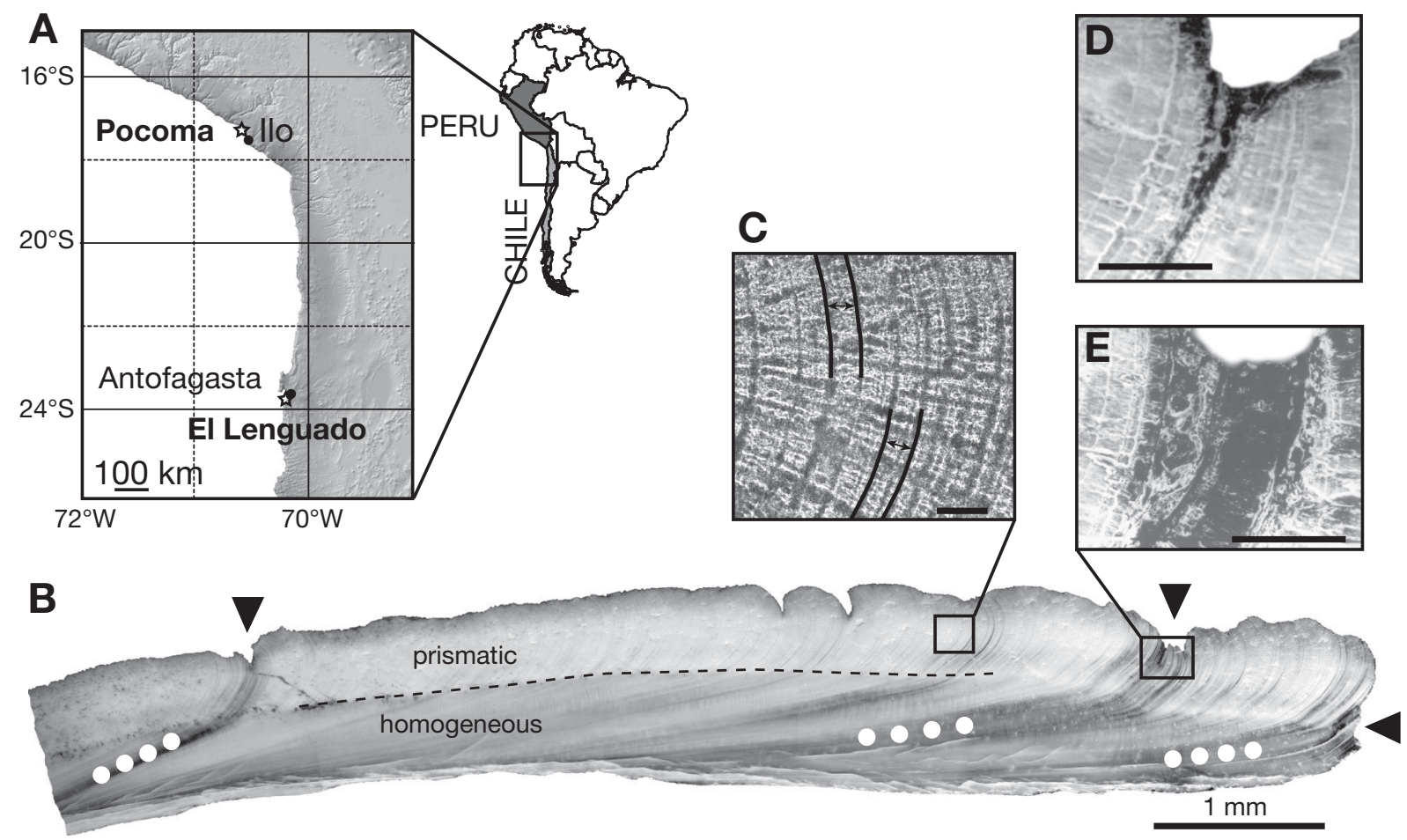

Fig. 1. (A) Sampling sites (stars). (B-E) Protothaca thaca. Structures and microstructures of the aragonitic shell. (B) Major growth anomalies (MGA); black triangles: surface grooves; white dotted lines: thick organic-rich layers (polished thick section, diffused light). (C) Daily growth increments. Arrows: growth rings of 1 day (acetate peel replicate, transmitted light). (D) Sporadic growth anomaly (retro-diffused electron SEM image). (E) MGA (retro-diffused electron SEM image). Scale bars for $(C)-(E)=100 \mu m$ 


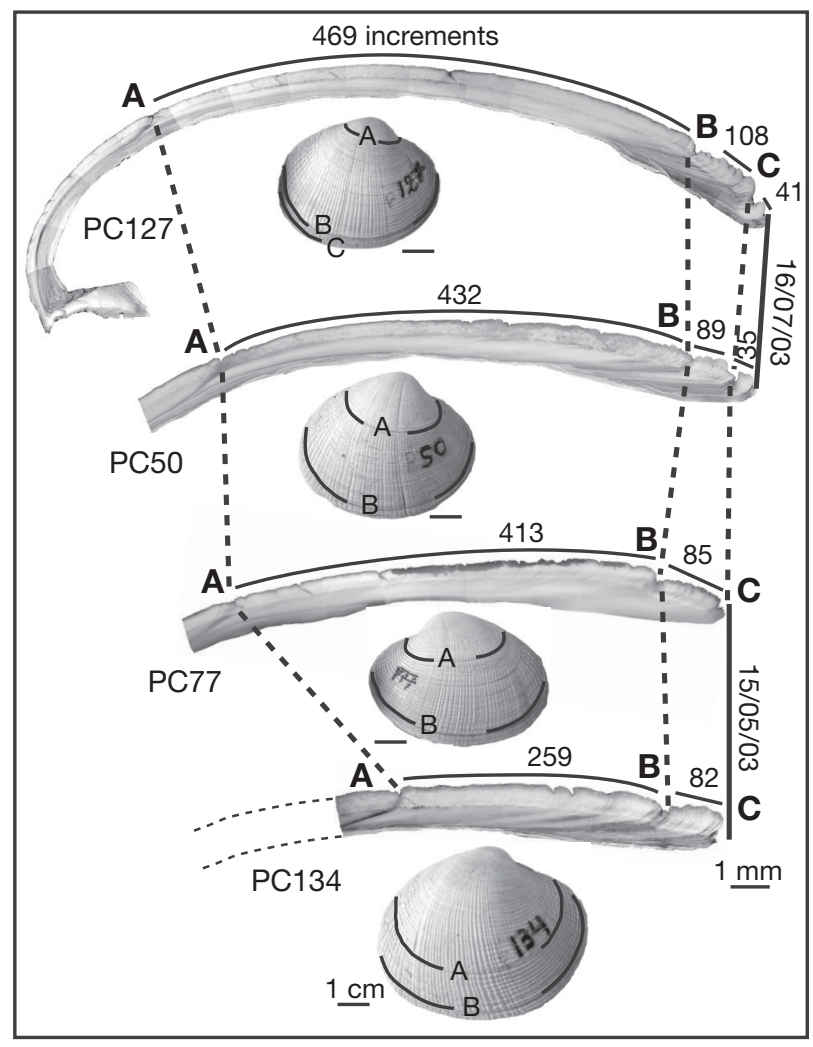

Fig. 2. Protothaca thaca. Identification of major growth anomalies (MGAs) in 4 shells (identification nos. given) from Pocoma (Peru). A, B and C are MGAs on valves (scale bar $=1 \mathrm{~cm}$ ) and on thick polish sections (diffused light; scale bar $=1 \mathrm{~mm}$ ); no. of daily growth increment between MGAs given above each section. Solid vertical lines and dates (right): end of growth. MGAs connected by dotted lines between shells

\subsection{Major growth anomalies (MGAs)}

Growth anomalies in Protothaca thaca shells consist of an organic-rich layer associated with a depression on the surface of the shell (Fig. 1B). Relatively thin growth anomalies, 5 to $40 \mu \mathrm{m}$ thick (Fig. 1D), which are irregularly distributed in the shell are interpreted as short non-periodic stress events like storms, predation attempts, etc. These irregular growth anomalies might also be related to spawning events, as $P$. thaca reproduction can occur in various months of the year (Henríquez et al. 1981).

Major growth anomalies (MGAs) are characterized by organic-rich layers of 50 to $400 \mu \mathrm{m}$ thickness and a more conspicuous groove at the surface of the shell (Figs. 1B \& 2). The microgrowth increment width is drastically reduced in MGAs (Fig. 3). We observed 3 MGAs (denoted A, B and C in Fig. 2) in P. thaca shells from Pocoma. The relative position of MGAs A and B in the shells depends on the age of the individual: in young individuals with an elevated growth rate (e.g.
PC127; Fig. 2, top), the distance between $\mathrm{A}$ and $\mathrm{B}$ is greater than in older individuals (e.g. PC134; Fig. 2, bottom). If MGAs A and B (and, by extension, C) represent records of the same events in the Pocoma population, the age dependence of the position of A and B should be reproducible. The distances umbo-A and A-B were measured on the surface of 21 Pocoma shells and these age-dependent distances were highly correlated $\left(\mathrm{R}^{2}=0.94\right)$. Pocoma $P$. thaca of different ages have thus recorded the same events at different periods in their life. MGA $\mathrm{C}$ is located at the ventral margin of Shells PC77 and PC134, which can be dated precisely thanks to the staining experiment. The calcein baths were highly stressful for the specimens, and lengthwise growth ceased after the first marking. Thus, for the PC77 and PC134 samples, the end of MGA $C$ is recorded at around 15 May 2003. The position of MGA C in PC127 and PC50 is determined by intercomparison of the shells and shell sections (Fig. 2).

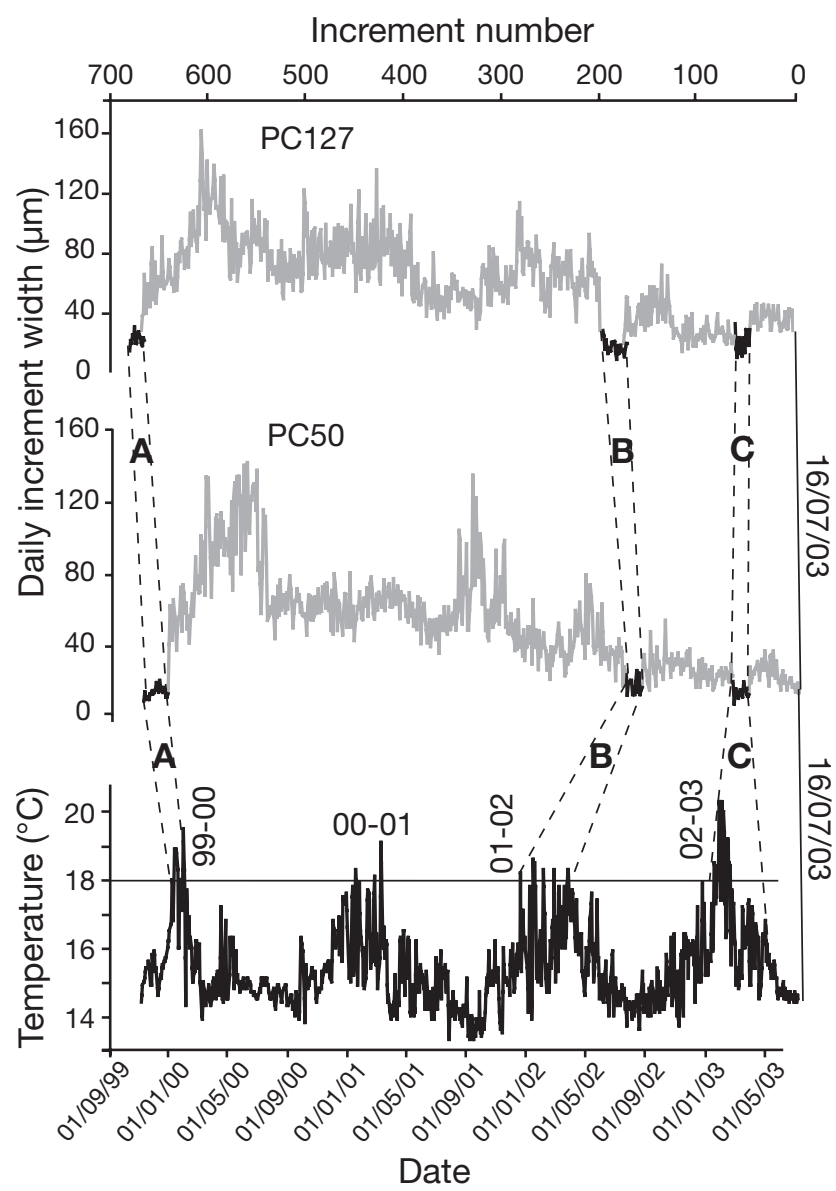

Fig. 3. Relation between recorded sea surface temperature (SST, bottom panel) and daily growth increment width variations in Protothaca thaca shells PC127 and PC50. Major growth anomalies A, B and C represented by small daily increments ('summer checks') are in black and related to the corresponding high summer SSTs. Solid lines at right: end of growth 


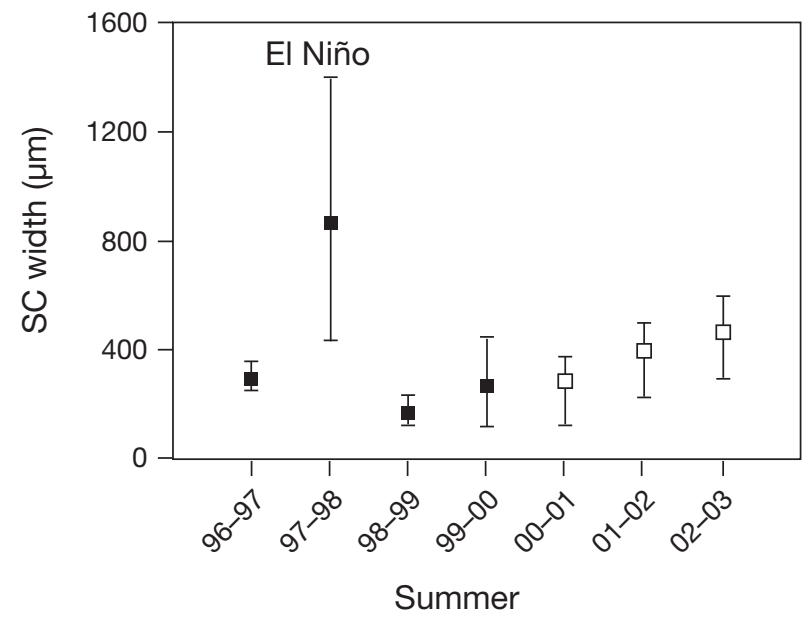

Fig. 4. Protothaca thaca. Means, minima and maxima of 'summer check' (SC) widths in shells (mean and range; $\mathrm{n}=42$ $\mathrm{SC})$. Filled squares: El Lenguado (Chile) $(\mathrm{N}=6)$. Empty squares: Pocoma (Peru) $(\mathrm{N}=7)$

To analyze which events induced the formation of MGA in the Protothaca thaca shells, microgrowth increment width variations were correlated with SST (Fig. 3); similar patterns were observed in PC77 and PC134 (not shown). MGA C occurred before mid-May 2003 (austral autumn) and <50 increments were counted between MGA $\mathrm{C}$ and the date on which the specimens were sacrificed. MGA $C$ thus corresponds to the austral summer 2002-2003. The MGA that occurred before MGA C, i.e. MGA B, is assigned to the austral summer 2001-2002. The number of 'daily' growth increments between A and B greatly exceeds the number of days in 1 year (Fig. 2). MGA A is therefore interpreted to correspond to summer 1999-2000 (Fig. 3). The overall decrease in growth rate and the decrease in the number of increments counted from summer 2000 to the date of sacrifice are in agreement with ontogenic development. The summers 19992000, 2001-2002 and 2002-2003 were those for which SST exceeded $18^{\circ} \mathrm{C}$ either almost continuously for $>3$ wk (1999-2000, 2002-2003) or repeatedly over 3 mo (2001-2002). When these SST conditions are not reached, no MGA is observed in the $P$. thaca shells (summer 2000-2001 between A and B). MGA were called 'summer check' (SC).

\subsection{MGAs and El Niño}

In the 6 El Lenguado specimens of Protothaca thaca collected in December 2000, 4 MGA were identified and assigned to the summers between 1996-1997 and 1999-2000. The MGA attributed to the strong 19971998 El Niño event was characterized in most of the shells by an alternation of normal growth (lightcoloured layers) and reduced growth (organic-rich layer), rather than by a continuous thick organic-rich layer. A total of 42 SCs measured in 13 specimens, including those from Pocoma, showed that the strong 1997-1998 El Niño event led not only to the widest SC of the population (mean width $868 \mu \mathrm{m}_{\text {; }}$ significantly wider than SC from other years, $\mathrm{p}<0.001)$ but also to the most varied individual response (Fig. 4).

\section{DISCUSSION}

\subsection{Environmental significance of MGAs}

Shell growth reduction or cessation is linked not only to specific SST conditions, but rather to a combination of environmental changes, including salinity and reduced food availability. In addition to other environmental and physiological parameters, food availability is one of the most important factors that controls molluscan shell growth rate (Witbaard 1996, Sato 1997, Schöne et al. 2005). The absence of SC-showing 'normal' summer growth-may indicate not only anomalously reduced SST (La Niña period), but also favourable environmental conditions. La Niña events generally lead to an increase in primary production, as reported for the 1996-1997 and 1998-1999 periods (Thomas et al. 2001, Carr et al. 2002). We surmise that the La Niña 2000-2001 summer induced both lower SST (see Fig. 3) and higher productivity.

\subsection{MGAs and El Niño}

Several studies showed that the strong 1997-1998 El Niño event along the Peruvian-Chilean coast was characterized by the occurrence of 2 El Niño maxima (June-July 1997 and December 1997-January 1998) separated by a relaxation period (Blanco et al. 2001, Carr et al. 2002, Escribano et al. 2004). During the El Niño pulses, SST, salinity and oxygenation of the water column increased (Escribano et al. 2004). The spatial pattern and concentrations of chlorophyll closely followed those of the SST, with low values during El Niño peaks and high values during the relaxation period (Thomas et al. 2001, Carr et al. 2002, Escribano et al. 2004). This succession of environmental conditions that were either potentially unfavourable (El Niño peaks with high SST and low primary production) or favourable (relaxation period with lower SST and highest productivity) during the 1997-1998 El Niño event may explain the specific microstructural pattern of the Protothaca thaca El Niño SC as well as the variable individual response observed. 


\section{CONCLUSIONS}

The sclerochronological analysis of recent PeruvianChilean Protothaca thaca indicates that the width variations in microgrowth increments may be related to the tidal cycle. Two types of growth anomalies were evidenced. The finest growth anomalies were interpreted as temporary stress events, while MGAs were attributed to anomalous summer environmental conditions, e.g. high SST over a longer time period, and named 'summer check'. During La Niña events, reduced summer SST and enhanced primary productivity lead to the absence of SC formation. The lifespan of bivalves (i.e. the time span of environmental variations registered) established from counting of MGAs should be used with caution, particularly in fossil specimens, as the environmental conditions which determine the formation of annual growth rings must be identified for each species and environment. In specimens collected in 2000, long-lasting high SST and associated environmental changes related to the 1997-1998 El Niño event led to the widest SC. We conclude that $\mathrm{SC}$ widths in fossil $P$. thaca shells are a proxy of paleo-ENSO events.

More work is needed to define the environmental conditions that induce SC formation in Protothaca thaca shells, particularly with regard to primary production. This study provides a basis for the interpretation of $P$. thaca shell microstructures, an essential step towards the calibration of proxies in modern shells. Geochemical analyses of shells, which are currently under way, should provide new clues to identify and evaluate the relative importance of the different environmental parameters responsible for MGA formation in P. thaca shells.

Acknowledgements. This study was supported by PALEOTROPIQUE (L'Institute de Recherche pour le Développement, IRD) and the CONCHAS project, PNEDC. We thank S. Caquineau (IRD, Bondy, France) and J.-P. Cuif (Paleontology Unit, University of Paris XI, Orsay, France) for SEM imaging. We thank S. Zevallos (Pocoma), L. El Jouhari, N. Guzmán (Ilo Station) and students (Facultad de Recursos del Mar, University of Antofagasta for the realisation and follow-up of staining experiments and SST data. We are grateful to O. Heilmayer for his constructive comments and English corrections on the manuscript. We also thank 2 anonymous referees for their critical reviews.

\section{LITERATURE CITED}

Arntz WE (1986) The two faces of El Niño 1982-1983. Meeresforsch 31:1-46

Arntz WE, Tarazona J (1990) Effects of El Niño 1982-83 on benthos, fish and fisheries off the South American Pacific coast. In: Glynn PW (ed) Global ecological consequences of the 1982-83 El Niño-Southern Oscillation. Elsevier, Amsterdam, p 323-360

Barriga ER, Quiroy MR (2002) Impacts of El Niño and La Niña events on the populations of clams (Mesodesma donacium, Lamarck 1818) along the Southern Peruvian coast. Investig Mar 30:137-135

Blanco JL, Thomas AC, Carr ME, Strub PT (2001) Seasonal climatology of hydrographic conditions in the upwelling region off northern Chile. J Geophys Res 106:11454-11467 (2000JC000540)

Buick DP, Ivany LC (2004) 100 years in the dark: extreme longevity of Eocene bivalves from Antarctica. Geology 32:921-924

Carr ME, Strub PT, Thomas AC, Blanco JL (2002) Evolution of 1996-1999 La Niña and El Niño conditions off the western coast of South America: a remote sensing perspective. J Geophys Res C 107:3236, doi:3210.1029/ 2001JC001183

Carré M, Bentaleb I, Fontugne M, Lavallée D (2005) Strong El Niño events during the early Holocene: stable isotope evidence from Peruvian sea shells. Holocene 15:42-47

El Jouhari L, Pierre C, Saliège J, Ortlieb L, Soler P (2001) Calibration of the oxygen isotopic composition of bivalve shells (Protothaca thaca, Veneridae) from the northern Chile coast. EOS Trans Am Geophys Union, Fall Meet Suppl 82, PP11A-0449

Escribano R, Daneri G, Farias L, Gallardo VA and 7 others (2004) Biological and chemical consequences of the 1997-1998 El Niño in the Chilean coastal upwelling system: a synthesis. Deep-Sea Res Part II 51:2389-2411

Goodwin DH, Flessa KW, Schöne BR, Dettman DL (2001) Cross-calibration of daily growth increments, stable isotope variation, and temperature in the Gulf of California bivalve mollusk Chione cortezi: implications for paleoenvironmental analysis. Palaios 16:387-398

Hall CA Jr, Dollase WA, Corabató CE (1974) Shell growth of Tivela stultorum (Mawe, 1826) and Callista chione (Linnaeus, 1758) (Bivalvia): annual periodicity, latitudinal differences, and diminution with age. Paleogeogr Paleoclimatol Paleoecol 15:33-61

Henríquez R, Barboza P, Taipa E, Toro C (1981) Variación anual de la gónada de la almeja Protothaca thaca (Molina, 1782): análysis histológico. J Cienc Mar 34

Jones DS (1981) Annual growth increments in shells of Spisula solidissima record marine temperature variability. Science 211:165-167

Jones DS (1983) Sclerochronology: reading the record of the molluscan shell. Am Sci 71:384-391

Jones DS, Quitmyer IR (1996) Marking time with bivalve shells: oxygen isotopes and season of annual increment formation. Palaios 11:340-346

Kennish MJ, Olsson RK (1975) Effects of thermal discharges on the microstructural growth of Mercenaria mercenaria. Environ Geol 1:41-64

Lutz RA, Rhoads DC (1980) Growth patterns within the molluscan shell, an overview. In: Rhoads DC, Lutz RA (eds) Skeletal growth of aquatic organisms: biological records of environmental change, Vol 1. Plenum Press, New York, p 203-255

Moore JD (1991) Cultural responses to environmental catastrophes: post-El Niño subsistence on the prehistoric north coast of Peru. Latin Am Antiq 2:27-47

Ortlieb L, Ghaleb B, Hillaire-Marcel C, Macharé J, Pichet P (1992) Déséquilibres U/Th, rapports allo/isoleucine et teneurs en ${ }^{18} \mathrm{O}$ des mollusques de dépôts littoraux pléistocènes du sud du Pérou: une base d'appréciation chronostratigraphique. CR Acad Sci Paris 314 (Ser II):101-107

Ortlieb L, Diaz A, Guzman N (1996) A warm interglacial episode during oxygen isotope stage 11 in northern Chile. Quat Sci Rev 15:857-871 
Perrier C, Hillaire-Marcel C, Ortlieb L (1994) Paléogéographie littorale et enregistrement isotopique $\left({ }^{13} \mathrm{C},{ }^{18} \mathrm{O}\right)$ d'évènements de type El Niño par les mollusques holocènes et récents du Nord-Ouest péruvien. Geogr Phys Quat 48:23-38

Reitz EJ (1988) Faunal remains from Paloma, an archaic site in Peru. Am Anthropol 90:310-322

Richardson CA (2001) Molluscs as archives of environmental changes. Oceanogr Mar Biol Annu Rev 39:103-164

Rollins HB, Sandweiss DH, Brand U, Rollins JC (1987) Growth increment and stable isotope analysis of marine bivalves: implications for the geoarchaeological record of El Niño. Geoarchaeol 2:181-197

Sato S (1997) Shell microgrowth patterns of bivalves reflecting seasonal change of phytoplankton abundance. Paleontol Res 1:260-266

Schöne BR, Goodwin DH, Flessa KW, Dettman DL, Roopnarine PD (2002a) Sclerochronology and growth of the bivalve mollusks Chione (Chionista) fluctifraga and $C$. (Chionista) cortezi in the northern Gulf of California, Mexico. Veliger 45:45-54

Schöne BR, Lega J, Flessa KW, Goodwin DH, Dettman DL (2002b) Reconstructing daily temperatures from growth rates of the intertidal bivalve mollusk Chione cortezi (northern Gulf of California, Mexico). Paleogeogr Paleoclimatol Paleoecol 184:131-146

Schöne BR, Tanabe K, Dettman DL, Sato S (2003) Environmental controls on shell growth rates and delta O-18 of the shallow-marine bivalve mollusk Phacosoma japonicum in Japan. Mar Biol 142:473-485

Editorial responsibility: Nils Chr. Stenseth, Oslo, Norway
Schöne BR, Houk SD, Freyre Castro AD, Fiebig J, Oschmann W (2005) Daily growth rates in shells of Arctica islandica: assessing sub-seasonal environmental controls on a longlived bivalve mollusk. Palaios 20:78-92

Takesue RK, van Geen A (2004) Mg/Ca, Sr/Ca, and stable isotopes in modern and Holocene Protothaca staminea shells from a northern California coastal upwelling region. Geochim Cosmochim Acta 68:3845-3861

Tanabe K (1988) Age and growth rate determinations of an intertidal bivalve, Phacosoma japonicum, using internal shell increments. Lethaia 21:231-241

Thomas AC, Blanco JL, Carr ME, Strub PT, Osses J (2001) Satellite-measured chlorophyll and temperature variability off northern Chile during the 1996-1998 La Niña and El Niño. J Geophys Res 106:899-915 (1999JC000052)

Urban HJ (1994) Upper temperature tolerance of ten bivalve species off Peru and Chile related to El Niño. Mar Ecol Prog Ser 107:139-145

Urban HJ, Campos B (1994) Population dynamics of the bivalves Gari solida, Semele solida and Protothaca thaca from a small bay in Chile at $36^{\circ} \mathrm{S}$. Mar Ecol Prog Ser 115: 93-102

Witbaard R (1996) Growth variations in Arctica islandica L. (Mollusca): a reflection of hydrography-related food supply. ICES J Mar Sci 53:981-987

Witbaard R (1997) Tree of the sea. The use of the internal growth lines in the shells of Arctica islandica (Bivalvia, Mollusca) for the retrospective assessment of marine environmental change. PhD thesis, Rijksuniversiteit, Groningen

Submitted: August 2, 2005; Accepted: March 5, 2006 Proofs received from author(s): March 22, 2006 